\title{
A Bibliometric Analysis on No-Show Research: Status, Hotspots, Trends and Outlook
}

\author{
Cheng Wang ${ }^{1}{ }^{\oplus}$, Runhua Wu ${ }^{1}$, Lili Deng ${ }^{2, *}$, Yong Chen ${ }^{1}$ and Yingde $\mathrm{Li}^{1}$ and Yuehua Wan ${ }^{3,4, *}$ \\ 1 Institute of Industrial Engineering, Zhejiang University of Technology, Hangzhou 310023, China; \\ cwang@zjut.edu.cn (C.W.); WrhLeon@163.com (R.W.); cy@zjut.edu.cn (Y.C.); liyingde2008@sina.com (Y.L.) \\ 2 School of Management, Zhejiang University of Technology, Hangzhou 310023, China \\ 3 Institute of Information Resources, Zhejiang University of Technology, Hangzhou 310023, China \\ 4 Library, Zhejiang University of Technology, Hangzhou 310023, China \\ * Correspondence: denglili@zjut.edu.cn (L.D.); wanyuehua@zjut.edu.cn (Y.W.)
}

Received: 2 April 2020; Accepted: 9 May 2020; Published: 13 May 2020

check for updates

\begin{abstract}
No-show is a thorny issue within the social scope. It not only affects the sustainability of service system operation but also causes heavy irretrievable losses. To maintain and develop the sustainability of service, this paper adopts bibliometric technology to reflect the current status and future prospects about no-show research. And we strive to explore and summarize appointment scheduling methods for no-show problems. The bibliometric analysis was carried out from various aspects including research areas, countries/regions, institutions, journals, authors and author keywords based on papers harvested from Web of Science Core Collection database. The total 1197 papers show that the United States is in a leading position in this field, followed by England and Canada. University of London is the most productive institution with the highest total citations and H-Index. BMC Health Services Research ranks first as the most productive journal, followed by European Journal of Operational Research and Production and Operations Management. Through the analysis of hot articles, we can conclude that how to reduce the impact of no-shows on the sustainability of service systems has become the main research direction. In addition to appointment scheduling, other effective methods are also mentioned. Further study on these methods will be a major research direction in the future.
\end{abstract}

Keywords: health-care; no-shows; bibliometrics; appointment system; appointment scheduling; overbooking; open access scheduling

\section{Introduction}

There are many no-show events in our daily life that may not receive widespread attention. For example, guests who set a place in a restaurant did not arrive; citizens did not attend the jury as agreed; senior executives with busy business did not remember that there was another meeting to hold; patients made appointments but they did not show up. From a micro perspective, every no-show event is just like a trivial matter that often happens around us. At a macro level, because thousands of identical events occur per year, these seemingly minor absences are not conducive to the sustainable development of various industries, and more importantly, no-show problems actually have had a huge impact on the economy, especially in the health care industry.

The health care industry accounted for approximately $15 \%$ of the gross domestic product of the United States. Health care expenditures are growing at such a rate that the amount of public funds needed to finance health care (it currently stands at $45 \%$ of all health care expenditures) is expected to be double by 2050 [1]. However, the no-show problem may result in significant financial losses [2], which hinders the sustainable development of health care industry. Most health service providers 
reported a high no-show rate ranging from $23 \%$ to $34 \%$ [3,4]. No-shows not only undermine continuity of care but also may lead to poor patient health outcomes [5,6]. Another study found that $31 \%$ of appointments were either canceled or missed over a single year, which resulted in an economic loss of a clinic accounting for 3\% to $14 \%$ of the clinic's total yearly income [2]. Actually, in addition to health care [7], the issue of no-show frequently occurs in all walks of life, such as but not limited to: revenue management [8], engineering applications [9], education [10], service industry [11], which has caused great distress to society. That is why many researchers work on the no-show problem. It is necessary to identify why people miss their appointments and it is of great interest for us to understand what measures to implement for reducing no-shows.

There has been a lot of literature on no-show over the past two decades, which focus on different research fields and propose many measures or strategies to reduce the impact of this problem. Subramanian et al. [12] formulated a dynamic programming model to consider airline seat allocation on a single-leg flight with multiple fare classes instead of omitting the effects of cancellation and no-shows in revenue management. Mobile health is defined as the application of mobile computing and communication technologies in health care and public health $[13,14]$. Behavior change interventions (including no-show) and reminders both fall under the umbrella of mobile health. Overbooking is a commonly adopted strategy for scheduling multiple patients in one appointment slot to hedge against the risk that some of them do not show up $[15,16]$. The no-show problem has gradually become a hotspot that more and more researchers are studying. And we want to combine existing references with a bibliometric analysis method to show the current status and development of no-show research, and discuss different resolution strategies that can be adopted so that researchers can better understand future trends and directions about the topic of no-show.

Bibliometrics was first proposed by Alan Prichard in 1969 [17]. As an effective tool to quantitatively analyze the sociological characteristics of the literature [18], the bibliometric analysis can reveal contributions of different countries/regions, collaboration networks, clusters of scientific terms, and transition of focus in a research field [19]. It highlights leading journals and articles published, presenting an intuitively research trend. It has been widely used in economics [20,21], chemistry [22], computer science [23], medicine [24], management [25], complex decision-making problems [26], etc. Interests about the bibliometric analysis of various research topics have increased sharply in recent years [27].

This paper aims to present a general overview of the no-show issue from the following aspects: (1) trends in publishing articles with on the topic of no-show; (2) the major contributors: research fields, countries/regions, institutions, authors; (3) cooperation among countries/regions, institutions, authors; (4) journals with the highest output and highest impact; (5) articles with high citation; (6) research interests and emerging trends by analyzing the author keywords. This study manifests the research hotspots of no-show research, which enables readers to understand the theoretical key factors and practical contributions as well as the future challenges of this issue.

The remainder of this paper is organized as follows. Section 2 shows the data sources, search methods and analysis tools. Section 3 provides the results of the study and some discussion about no-show fields. Section 4 summarizes some of existing methods and measures to reduce or solve the problem of no-shows as well as discussing the future trends. Conclusions are presented in Section 5.

\section{Methodology}

The bibliometric analysis is based on the publications related to the issue of no-shows published from 1985 to 2020 in Web of Science (WoS) Core Collection database. Papers were retrieved through the Science Citation Index Expanded (SCIE) or Social Sciences Citation Index (SSCI) on 14 February 2020 with the search formula: TS = ("no-show" OR "no-shows" OR" non-attendance" OR "missed appointment*" OR "failed appointment*" OR "fail* to attend" OR "non-arrival") AND $\mathrm{TS}=$ (appointment OR appointments OR booking OR revenue management OR reservation), selecting the literature type as article and review in the subject area. The results show that 1197 papers from 
79 countries/regions are collected by InCites data set indexed till 14 February 2020. The analysis of keywords and international cooperation was done through Dervent Data Analyzer (DDA) software and the Impact Factors (IF) of journals were displayed according to InCites Journal Citation Reports 2018.

Some evaluation indicators used in this paper can be explained as follows: TA refers to the total number of articles. TPR $\%$ means that the percentage of articles of journals in total publications, and it is calculated as TA divided by the total number of papers. TC refers to the total number of citations which can be observed by InCites data. ACPP means that average citations per publication, and it is calculated as TC divided by TA. IC refers to the number of international collaboration papers. The $H$-Index is defined as the maximum value of $H$ such that the given author/journal has published $H$ papers that have each been cited at least $H$ times. We also can conveniently get the $H$-index of each author from the database. It is worth noting that some related publications may not be included in the above formula and database. If there are no needed words in the title, abstract or keywords, some related publications could be ruled out. These issues may produce some deviations and certain limitations.

\section{Results Analysis}

According to the search condition in our selected database, the first paper [28] on the issue of no-shows was published in 1991. From then on, there has been a significant growth in the total number of publications on related topics. Up to now, as mentioned in Section 2, 79 countries/regions have contributed to the no-show research field with 1197 publications. The growth trend of the number of publications on no-show research is shown in Figure 1. From 1991 to 2003, the annual growth in the number of publications tends to be stable. But the overall number shows an upward trend from the perspective of the cumulative distribution. Compared with a total of 179 papers published from 1991 to 2003, the number of related publications in this field has increased to 889 from 2004 to 2016 , with a growth rate of $79.87 \%$. In terms of cumulative quantity, the second stage clearly shows a significant upward trend in the field of no-show research. According to statistics, the average number of papers published per year is approximately 95 from 2014 to 2019. Since 2020, 7 new articles have been added to the search scope, which is a good phenomenon. This trend indicates that the no-show problem has become a hot topic of social concern and scholarly research and it will continue to attract widespread attention throughout the world.

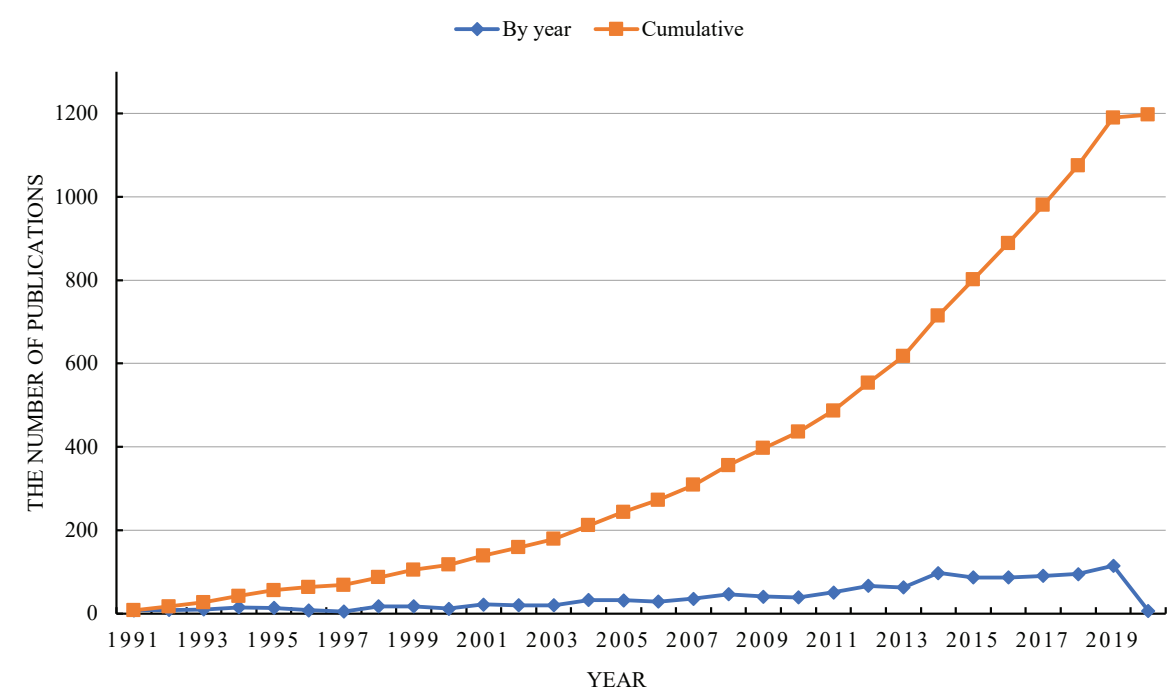

Figure 1. The number of published documents from the global related to no-show. 


\subsection{Research Areas and Leading Countries/Regions}

Generally, the research area can appropriately reflect the scope of the research topic application. There are 110 various research areas with 1197 papers by querying the WoS categories. Figure 2 shows the bubble chart of the top $20 \mathrm{WoS}$ research areas by year.

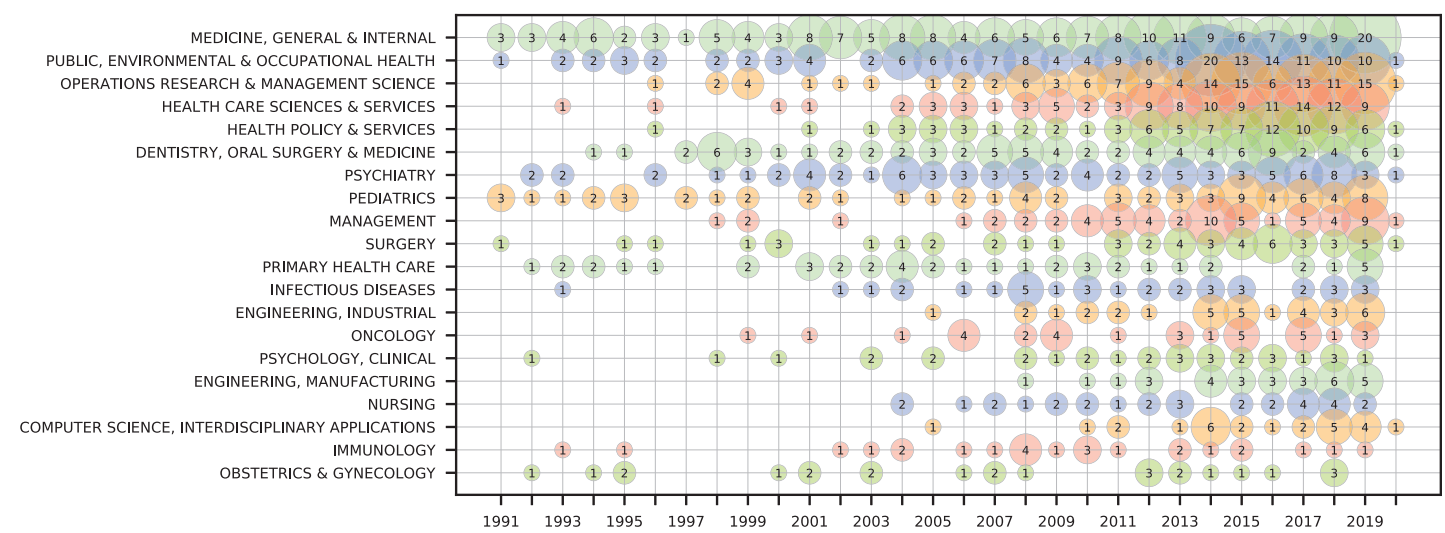

Figure 2. The top $20 \mathrm{WoS}$ research areas in no-show research by year.

The number of each bubble indicates the number of papers published in the field each year, as calculated by the WoS category. The size of the bubbles is proportional to the number of publications in research areas. The color of the bubbles is only used to distinguish various research areas. By comparing the size of the bubble horizontally, the growth trend of each research field can be derived from the bubble chart, especially in recent five years. It is possible to compare the size of the bubbles in the longitudinal direction to work out what is the hot research area of the year. Obviously, "Medicine, General \& Internal" dominates the research area list with 187 papers, followed by "Public, Environmental \& Occupational Health", "Operations Research \& Management Science", "Health Care Sciences \& Services", "Health Policy \& Services" and "Dentistry, Oral Surgery \& Medicine". Because of the accumulation of papers in the early years, "Medicine, General \& Internal" temporarily ranks first. At the same time, "Public, Environmental \& Occupational Health" and "Operations Research \& Management Science", which rank second and third respectively, also show impressive development momentum with a total of 79 and 75 papers published from 2014 to 2020, respectively.

Table 1 shows the top 20 countries/regions in terms of the number of publications related to no-show areas. The United States is the most productive country with a total of 539 papers, followed by England (225) and Canada (65). Australia (55) and China Mainland (38) are ranked fourth and fifth, respectively. As for the average citations per publication (ACPP), the top three countries have high ACPP values exceeding 20. It is worth mentioning that despite the small number of publications, the average citation per publication in Wales is the highest (48.23). Furthermore, the ACPPs of Norway (13) and France (12) are ahead of some countries/regions in the list with 17.54 and 18.58. According to the number of international collaboration papers (IC), the United States leads the ranking with total 70 international cooperation papers, followed by England with 41 and Canada with 23. 
Table 1. The top 20 most productive countries/regions in no-show research.

\begin{tabular}{ccccccc}
\hline Rank & Country/Region & TA & TPR\% & TC & ACPP & IC \\
\hline 1 & United States & 539 & 45.03 & 12061 & 22.38 & 70 \\
2 & England & 225 & 18.80 & 5851 & 26.00 & 41 \\
3 & Canada & 65 & 5.43 & 1661 & 25.55 & 23 \\
4 & Australia & 55 & 4.59 & 1004 & 18.25 & 15 \\
5 & China Mainland & 38 & 3.17 & 274 & 7.21 & 13 \\
6 & Scotland & 36 & 3.01 & 631 & 17.53 & 9 \\
7 & Netherlands & 30 & 2.51 & 590 & 19.67 & 17 \\
8 & Sweden & 23 & 1.92 & 300 & 13.04 & 9 \\
9 & Brazil & 20 & 1.67 & 205 & 10.25 & 2 \\
10 & Ireland & 20 & 1.67 & 250 & 12.50 & 5 \\
11 & Denmark & 20 & 1.67 & 330 & 16.50 & 9 \\
12 & Saudi Arabia & 18 & 1.50 & 95 & 5.28 & 5 \\
13 & Israel & 16 & 1.34 & 216 & 13.50 & 6 \\
14 & South Africa & 16 & 1.34 & 175 & 10.94 & 9 \\
15 & Spain & 15 & 1.25 & 92 & 6.13 & 3 \\
16 & Germany & 14 & 1.17 & 208 & 14.86 & 4 \\
17 & Wales & 13 & 1.09 & 627 & 48.23 & 4 \\
18 & Norway & 13 & 1.09 & 228 & 17.54 & 3 \\
19 & Singapore & 13 & 1.09 & 169 & 13.00 & 8 \\
20 & Hong Kong & 12 & 1.00 & 133 & 11.08 & 3 \\
\hline
\end{tabular}

TA, total articles; TPR $\%$, the percentage of articles of journals in total publications; TC, total citations; ACPP, average citations per publication; IC, the number of international collaboration papers.

The development momentum of a country in a certain field can also be represented by a bubble chart. As shown in Figure 3, in the field of no-show research, the United States has maintained its leading position around the world for a long time, and England is close behind. Canada, Australia, and China Mainland have also achieved great grades in recent years, and the research trend is generally on the rise. In addition, it can be seen that countries ranking upper and middle are actively catching up with the top 3 countries.

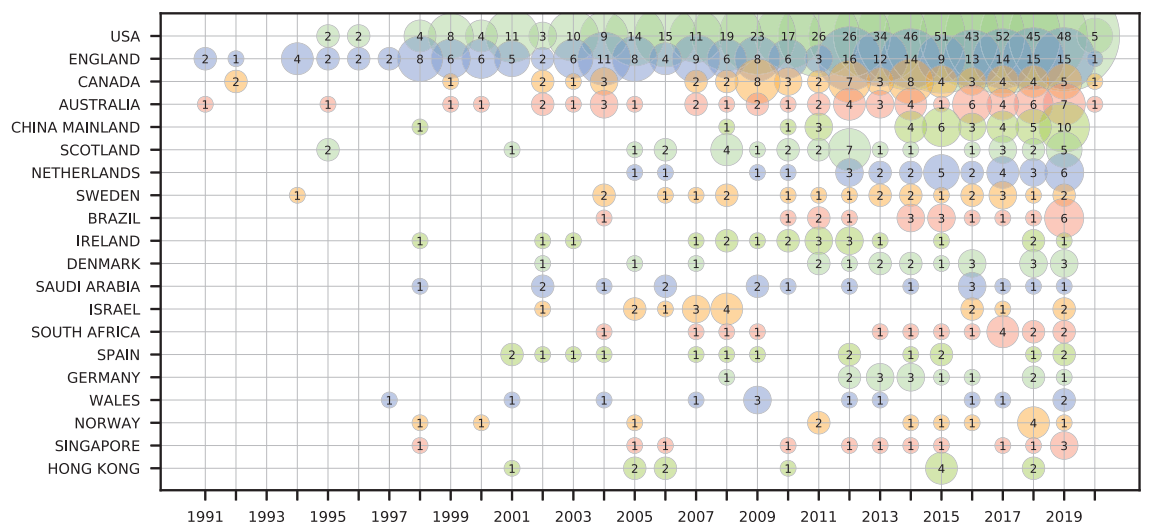

Figure 3. The top 20 most productive countries/regions in no-show research by year.

The rapid development of a research field also benefits from mutual cooperation. The collaborative relationship of the top 20 productive countries/regions is shown in Figure 4. The size of nodes is positively related to the total number of papers in each country. The lines represent the cooperative relationship between the two countries/regions. The thickness of a line indicates the strength of the cooperation between the two countries/regions. There is no doubt that the United States is the most active country that collaborates with other countries/regions, such as England, China Mainland, Netherlands and Canada. 


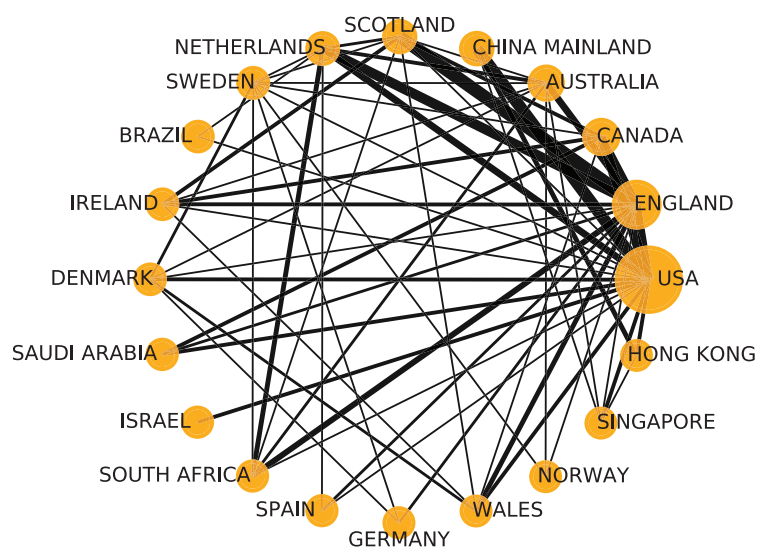

Figure 4. Collaboration matrix map among the top 20 productive countries/regions.

Table 2 shows the top 20 most productive institutions of publications in no-show research from 1985 to 2020, according to the total number of articles (TA), total citations (TC), and $H$-Index. Surprisingly, these institutions are almost all from England and the United States, except for the University of Toronto (15). University of London (69) is leading the way in this research publishing papers amounting to $5.80 \%$ of the total, followed by Harvard University (53) and University of California System (36). As for the ACPP, Imperial College London, Columbia University and University of London lead the list with 74.12, 37.44 and 37.26, respectively. Meanwhile, University of London also has the highest $H$-Index as 20. Compared with the research influence of the United States and England research institutions, other countries/regions still have a lot of room for improvement and have a long way to go.

Table 2. The top 20 most productive institutions from 1985 to 2020.

\begin{tabular}{|c|c|c|c|c|c|c|c|}
\hline Rank & Institutions & TA & TPR\% & TC & ACPP & H-Index & Country \\
\hline 1 & University of London & 69 & 5.80 & 2571 & 37.26 & 20 & England \\
\hline 2 & Harvard University & 53 & 4.43 & 1927 & 36.36 & 18 & USA \\
\hline 3 & University of California System & 36 & 3.00 & 530 & 14.72 & 14 & USA \\
\hline 4 & University College London & 35 & 2.92 & 1096 & 31.31 & 13 & England \\
\hline 5 & University of Texas System & 30 & 2.51 & 506 & 16.87 & 11 & USA \\
\hline 6 & University of North Carolina & 29 & 2.42 & 1000 & 34.48 & 13 & USA \\
\hline 7 & Massachusetts General Hospital & 23 & 1.92 & 483 & 21.00 & 11 & USA \\
\hline 8 & Johns Hopkins University & 19 & 1.59 & 613 & 32.26 & 11 & USA \\
\hline 9 & Duke University & 18 & 1.50 & 357 & 19.83 & 9 & USA \\
\hline 10 & Pennsylvania Commonwealth System of Higher Education & 18 & 1.50 & 281 & 15.61 & 8 & USA \\
\hline 11 & University of North Carolina Chapel Hill & 17 & 1.42 & 515 & 30.29 & 9 & USA \\
\hline 12 & University of Pennsylvania & 17 & 1.42 & 436 & 25.65 & 9 & USA \\
\hline 13 & State University System of Florida & 17 & 1.42 & 237 & 13.94 & 7 & USA \\
\hline 14 & University of Michigan System & 17 & 1.42 & 215 & 12.65 & 8 & USA \\
\hline 15 & Imperial College London & 17 & 1.42 & 1260 & 74.12 & 10 & England \\
\hline 16 & Kings College London & 17 & 1.42 & 453 & 26.65 & 9 & England \\
\hline 17 & University of Michigan & 16 & 1.34 & 213 & 13.31 & 8 & USA \\
\hline 18 & Columbia University & 16 & 1.34 & 599 & 37.44 & 11 & USA \\
\hline 19 & US Department of Veteran Affairs & 16 & 1.34 & 198 & 12.38 & 8 & USA \\
\hline 20 & University of Toronto & 15 & 1.25 & 202 & 13.47 & 8 & Canada \\
\hline
\end{tabular}

TA total articles; TPR\%, the percentage of articles of journals in total publications; TC, total citations; ACPP, average citations per publication.

\subsection{Contribution of Leading Journals}

Scholars who engaged in no-show research should learn more about journals in this field, which will facilitate the exchange and sharing of future academic achievements. 1197 papers related to no-show during 1985 to 2020 were published over 275 journals. As listed in Table 3, BMC Health Services Research takes the leading position with 21 papers, followed by Production and Operations 
Management (17), European Journal of Operational Research (17) and British Journal of General Practice (16). At the same time, we can also notice that the top journals can be mainly divided into two categories: health care and operations management. This confirms how frequently the no-show problem occurs, and how much it affects the sustainability of the service operation system.

Table 3. The top 20 most productive journals in no-show research.

\begin{tabular}{|c|c|c|c|c|c|c|}
\hline Rank & Journals & TA & TPR\% & TC & ACPP & IF \\
\hline 1 & BMC Health Services Research & 21 & 1.75 & 215 & 10.24 & 1.93 \\
\hline 2 & European Journal of Operational Research & 17 & 1.42 & 300 & 18.75 & 3.81 \\
\hline 2 & Production and Operations Management & 17 & 1.42 & 354 & 20.82 & 2.17 \\
\hline 3 & British Journal of General Practice & 16 & 1.34 & 401 & 25.06 & 4.43 \\
\hline 5 & British Dental Journal & 16 & 1.34 & 157 & 9.81 & 1.44 \\
\hline 6 & Journal of General Internal Medicine & 14 & 1.17 & 585 & 41.79 & 4.61 \\
\hline 7 & International Journal of STD \& AIDS & 11 & 0.92 & 111 & 10.09 & 1.50 \\
\hline 8 & BMJ Open & 10 & 0.84 & 33 & 3.30 & 2.38 \\
\hline 9 & PLoS One & 9 & 0.75 & 68 & 7.56 & 2.78 \\
\hline 10 & American journal of Orthodontics and Dentofacial Orthopedics & 9 & 0.75 & 179 & 19.89 & 1.91 \\
\hline 11 & AIDS Care-Psychological and Socio-Medical Aspects of AIDS/HIV & 9 & 0.75 & 248 & 27.56 & 2.11 \\
\hline 12 & Obesity Surgery & 9 & 0.75 & 222 & 24.67 & 3.60 \\
\hline 13 & Psychiatric Services & 9 & 0.75 & 260 & 28.89 & 2.25 \\
\hline 14 & Transportation Science & 8 & 0.67 & 379 & 47.38 & 3.31 \\
\hline 15 & Manufacturing \& Service Operations Management & 8 & 0.67 & 289 & 36.13 & 2.67 \\
\hline 16 & Health Care Management Science & 8 & 0.67 & 71 & 8.88 & 2.06 \\
\hline 17 & Journal of The Operational Research Society & 8 & 0.67 & 115 & 14.38 & 1.75 \\
\hline 18 & Journal of The Royal Society Medicine & 8 & 0.67 & 285 & 35.63 & 3.54 \\
\hline 19 & Journal of The American College of Radiology & 8 & 0.67 & 33 & 4.13 & 3.79 \\
\hline 20 & Family Practice & 7 & 0.58 & 368 & 52.57 & 1.99 \\
\hline
\end{tabular}

TA total articles; TPR $\%$, the percentage of articles of journals in total publications; TC, total citations; ACPP, average citations per publication; IF, impact factor.

Although Family Practice has a small total number of papers, its ACPP with 52.57 is the highest in the top 20 followed by Transportation Science (47.38) and Journal of General Internal Medicine (41.79). With respect to impact factor (IF), Journal of General Internal Medicine has the highest value of 4.61, followed by British Journal of General Practice (4.43), European Journal of Operational Research (3.81), Journal of The American College of Radiology (3.79) and Obesity Surgery (3.60). Similarly, in order to display the trend of the top 20 productive journals by year, the bubble chart was employed, as shown in Figure 5.

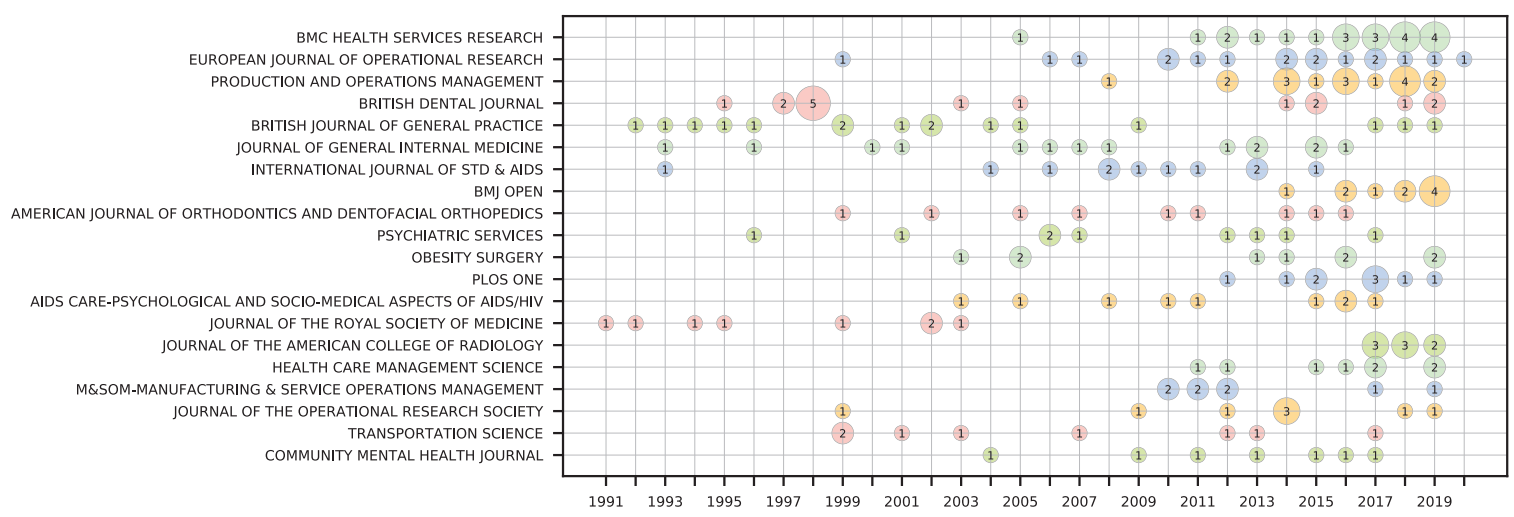

Figure 5. The top 20 most productive journals by year.

\subsection{Contribution of Leading Authors}

Understanding other researchers' study on the no-show issue can help in promoting the cooperation among scholars. Table 4 shows the top 20 prolific authors ranked by the number of published papers. Tang, Jiafu and Yan, Chongjun from Dongbei University of Finance \& Economics 
and Lawley, Mark from Purdue University are tied for the first position with the total number of 7 papers. When the number of papers published is relatively small, TC and $H$-Index are also good evaluation metrics. Car, Josip achieves a high $H$-Index as 4 while having the highest TC value with 359 among the top 20 authors. Although LaGanga, Linda R. published 5 papers in this field, his total citations reach up to 305, ranking only the second to Car, Josip. As for ACPP, Car, Josip has the highest ACPP value with 71.80, followed by Ziya, Serhan and Muthuraman, Kumar. Besides, the papers of the top 20 authors devoted themselves accounts for only $8.27 \%$ of the total publications, which means that a large number of researchers have dedicated themselves to this field, contributing to a total of 1197 publications. It is worth noting that this research area is only recently proposed, and the core author team has not yet been formed. Although the numbers in Table 4 are small, it also reflects that this is an emerging interdisciplinary study. And no-show research exists much room for future study.

Table 4. The top 20 authors' contributions in no-show research.

\begin{tabular}{|c|c|c|c|c|c|c|c|}
\hline Rank & Author & TA & TPR $\%$ & TC & ACPP & H-Index & Affiliation \\
\hline 1 & Tang, Jiafu & 7 & 0.58 & 32 & 4.57 & 3 & $\begin{array}{l}\text { Dongbei University of Finance \& } \\
\text { Economics Northeastern } \\
\text { University-China }\end{array}$ \\
\hline 2 & Yan, Chongjun & 7 & 0.58 & 19 & 2.71 & 3 & $\begin{array}{l}\text { Dongbei University of Finance \& } \\
\text { Economics Northeastern } \\
\text { University - China }\end{array}$ \\
\hline 3 & Lawley, Mark & 7 & 0.58 & 225 & 32.14 & 5 & Purdue University \\
\hline 4 & Muthuraman, Kumar & 6 & 0.50 & 205 & 34.17 & 4 & University of Texas Austin \\
\hline 5 & Jiang, Bowen & 6 & 0.50 & 19 & 3.17 & 3 & Northeastern University-China \\
\hline 6 & Huang, Y. & 6 & 0.50 & 33 & 5.50 & 3 & $\begin{array}{l}\text { New Mexico State University } \\
\text { Mayo Clinic }\end{array}$ \\
\hline 7 & Cayirli, Tugba & 5 & 0.42 & 145 & 29 & 3 & Ozyegin University \\
\hline 8 & Ziya, Serhan & 5 & 0.42 & 243 & 48.60 & 4 & $\begin{array}{l}\text { University of North Carolina } \\
\text { Chapel Hill }\end{array}$ \\
\hline 9 & Qu, Xiuli & 5 & 0.42 & 54 & 10.80 & 5 & $\begin{array}{l}\text { North Carolina A\&T State } \\
\text { University }\end{array}$ \\
\hline 10 & Shi, Jing & 5 & 0.42 & 48 & 9.60 & 5 & $\begin{array}{l}\text { North Dakota State University } \\
\text { Fargo }\end{array}$ \\
\hline 11 & LaGanga, Linda R. & 5 & 0.42 & 305 & 61 & 4 & $\begin{array}{l}\text { Mental Health Center of } \\
\text { Denver }\end{array}$ \\
\hline 12 & Ellis, David A. & 5 & 0.42 & 37 & 7.40 & 4 & $\begin{array}{l}\text { Lancaster University } \\
\text { University of Glasgow }\end{array}$ \\
\hline 13 & Car, Josip & 5 & 0.42 & 359 & 71.80 & 4 & $\begin{array}{l}\text { Imperial College London } \\
\text { University of Ljubljana } \\
\text { Singapore Management }\end{array}$ \\
\hline 14 & Yang, Kum Khiong & 5 & 0.47 & 72 & 14.4 & 2 & $\begin{array}{l}\text { University National University } \\
\text { of Singapore }\end{array}$ \\
\hline 15 & Denton, Brian T. & 4 & 0.47 & 83 & 20.75 & 3 & University of Michigan \\
\hline 16 & Kulkarni, Vidyadhar G. & 4 & 0.47 & 160 & 40 & 3 & $\begin{array}{l}\text { University of North Carolina } \\
\text { Chapel Hill }\end{array}$ \\
\hline 17 & Sockalingam, Sanjeev & 3 & 0.25 & 58 & 19.33 & 2 & University of Toronto \\
\hline 18 & Bard, Jonathan F. & 3 & 0.25 & 8 & 2.67 & 2 & University of Texas Austin \\
\hline 19 & Percac-Lima, Sanja & 3 & 0.25 & 45 & 15 & 3 & $\begin{array}{l}\text { Harvard University } \\
\text { Massachusetts General Hospital }\end{array}$ \\
\hline 20 & Williamson, Andrea E. & 3 & 0.25 & 33 & 11 & 3 & University of Glasgow \\
\hline
\end{tabular}

\subsection{An Analysis of the Most Cited Papers}

Tahamtan et al. proposed a series of factors that affect the number of citations, like the quality of the paper, organizational features, characteristics of title and references, novelty and interest of the subject, etc. [29]. His study indicates that some factors such as the journal impact factor, international cooperation and the number of authors may be closely related to the frequency of 
citations. Although the citation influence of the paper depends on various factors, it is still an important indicator for evaluating papers in the research field.

Among 1197 papers about no-shows which published from 1985 to 2020, 44 (3.68\%) papers have been cited more than 100 times. And 77 papers have been cited between 50 and 99 times, accounting for $6.43 \%$ of the total.

Table 5 presents the top 20 most highly cited publications. The earliest paper was published in 1992, while the most recent one was published in 2013. Only two papers are not about health care research on the issue of no-shows, titled "Poverty impedes cognitive function" published in Science by Mani et al. [30] and "Airline yield management with overbooking, cancellations, and no-shows" published in Transportation Science by Subramanian et al. [12], respectively. It indicates that health care is a hot topic in the research of no-show, and the top 3 papers can make a good illustration. The most highly cited paper "The effectiveness of mobile-health technologies to improve health care service delivery processes: A systematic review and meta-analysis" was published in PLoS Medicine by Free et al. [14]. In recent years, it dominates the list of total citations (904). Whereas "Poverty impedes cognitive function" and "Healthcare via cell phones: a systematic review" take the second and third positions due to total citations with 575 and 504. And the paper "Sensitivity and specificity of multimodal and ultrasound screening for ovarian cancer, and stage distribution of detected cancers: results of the prevalence screen of the UK Collaborative Trial of Ovarian Cancer Screening (UKCTOCS)" in Lancet Oncology by Menon et al. [31] also has gained a high total citation (485) and a high total citation per year (44.09), which to some extent reveals the widespread concern in this field.

Table 5. The top 20 most cited publications from 1985 to 2020.

\begin{tabular}{|c|c|c|c|c|c|}
\hline Rank & Author(PY) & Title & Journal & TC & TCY \\
\hline 1 & Free et al. (2013) [14] & $\begin{array}{l}\text { The effectiveness of mobile-health technologies } \\
\text { to improve health care service delivery } \\
\text { processes: A systematic review } \\
\text { and meta-analysis }\end{array}$ & PLoS Medicine & 904 & 129.14 \\
\hline 2 & Mani et al. (2013) [30] & Poverty impedes cognitive function & $\begin{array}{l}\text { Science } \\
\text { Telemedicine }\end{array}$ & 575 & 82.14 \\
\hline 3 & Krishna et al. (2009) [32] & Healthcare via cell phones: a systematic review & $\begin{array}{l}\text { Journal } \\
\text { and E-Health }\end{array}$ & 504 & 45.82 \\
\hline 4 & Menon et al. (2009) [31] & $\begin{array}{l}\text { Sensitivity and specificity of multimodal } \\
\text { and ultrasound screening for ovarian cancer, } \\
\text { and stage distribution of detected cancers: } \\
\text { results of the prevalence screen of the UK } \\
\text { Collaborative Trial of Ovarian Cancer } \\
\text { Screening (UKCTOCS) }\end{array}$ & Lancet Oncology & 485 & 44.09 \\
\hline 5 & Karter et al. (2001) [33] & $\begin{array}{l}\text { Self-monitoring of blood glucose levels } \\
\text { and glycemic control: The Northern California } \\
\text { Kaiser Permanente diabetes registry }\end{array}$ & $\begin{array}{l}\text { American Journal of } \\
\text { Medicine }\end{array}$ & 373 & 19.63 \\
\hline 6 & Gupta et al. (2008) [1] & $\begin{array}{l}\text { Appointment scheduling in health care: } \\
\text { Challenges and opportunities }\end{array}$ & IIE Transactions & 365 & 30.42 \\
\hline 7 & Macharia et al. (1992) [34] & $\begin{array}{l}\text { An overview of interventions to improve } \\
\text { compliance with appointment keeping } \\
\text { for medical-services }\end{array}$ & $\begin{array}{l}\text { Journal of } \\
\text { The American } \\
\text { Medicine } \\
\text { Association }\end{array}$ & 234 & 8.36 \\
\hline 8 & Beach et al. (2006) [35] & $\begin{array}{l}\text { Is the quality of the patient-provider } \\
\text { relationship associated with better adherence } \\
\text { and health outcomes for patients with HIV? }\end{array}$ & $\begin{array}{l}\text { Journal of General } \\
\text { Internal Medicine }\end{array}$ & 217 & 15.50 \\
\hline 9 & Syed et al. (2013) [36] & $\begin{array}{l}\text { Traveling Towards Disease: Transportation } \\
\text { Barriers to Health Care Access }\end{array}$ & $\begin{array}{l}\text { Journal of } \\
\text { Community Health }\end{array}$ & 210 & 30.00 \\
\hline 10 & Rhee et al. (2005) [37] & $\begin{array}{l}\text { Patient adherence improves glycemic control } \\
\text { The use of text messaging to improve }\end{array}$ & Diabetes Educator & 194 & 12.93 \\
\hline 11 & Leong et al. (2006) [38] & $\begin{array}{l}\text { attendance in primary care: a randomized } \\
\text { controlled trial }\end{array}$ & Family Practice & 180 & 12.86 \\
\hline 12 & Killaspy et al. (2000) [39] & $\begin{array}{l}\text { Prospective controlled study of psychiatric } \\
\text { out-patient non-attendance - Characteristics } \\
\text { and outcome }\end{array}$ & $\begin{array}{l}\text { British Journal of } \\
\text { Psychiatry }\end{array}$ & 178 & 8.90 \\
\hline
\end{tabular}


Table 5. Cont.

\begin{tabular}{|c|c|c|c|c|c|}
\hline Rank & Author(PY) & Title & Journal & TC & TCY \\
\hline 13 & Yu et al. (2007) [40] & $\begin{array}{l}\text { True outcomes for patients on antiretroviral } \\
\text { therapy who are "lost to follow-up" in Malawi }\end{array}$ & $\begin{array}{l}\text { Bulletin of } \\
\text { The World Health } \\
\text { Organization }\end{array}$ & 177 & 13.62 \\
\hline 14 & Swofford et al. (1996) [41] & $\begin{array}{l}\text { Substance use: A powerful predictor of relapse } \\
\text { in schizophrenia }\end{array}$ & $\begin{array}{l}\text { Schizophrenia } \\
\text { Research }\end{array}$ & 172 & 7.17 \\
\hline 15 & Lacy et al. (2004) [42] & $\begin{array}{l}\text { Why we don't come: Patient perceptions on } \\
\text { no-shows }\end{array}$ & $\begin{array}{l}\text { Annal of Family } \\
\text { Medicine }\end{array}$ & 170 & 10.63 \\
\hline 16 & $\begin{array}{l}\text { Subramanian et al. } \\
\text { (1999) [12] }\end{array}$ & $\begin{array}{l}\text { Airline yield management with overbooking, } \\
\text { cancellations, and no-shows }\end{array}$ & $\begin{array}{l}\text { Transportation } \\
\text { Science }\end{array}$ & 170 & 8.10 \\
\hline 17 & Gurol et al. (2013) [43] & $\begin{array}{l}\text { Mobile phone messaging reminders } \\
\text { for attendance at healthcare appointments }\end{array}$ & $\begin{array}{l}\text { Cochrane Database } \\
\text { of Systematic } \\
\text { Reviews }\end{array}$ & 164 & 23.43 \\
\hline 18 & $\begin{array}{l}\text { Satterthwaite et al. } \\
\text { (2014) [44] }\end{array}$ & $\begin{array}{l}\text { Neuroimaging of the Philadelphia } \\
\text { Neurodevelopmental Cohort }\end{array}$ & Neuroimage & 159 & 26.50 \\
\hline 19 & Gallacher et al. (2011) [45] & $\begin{array}{l}\text { Understanding patients' experiences of } \\
\text { treatment burden in chronic heart failure using } \\
\text { normalization process theory }\end{array}$ & $\begin{array}{l}\text { Annals of Family } \\
\text { Medicine }\end{array}$ & 157 & 17.44 \\
\hline 20 & Junghans et al. (2005) [46] & $\begin{array}{l}\text { Recruiting patients to medical research: double } \\
\text { blind randomised trial of "opt-in" versus } \\
\text { "opt-out" strategies }\end{array}$ & $\begin{array}{l}\text { British Medical } \\
\text { Journal }\end{array}$ & 157 & 10.47 \\
\hline
\end{tabular}

PY, publishing year; TC, total citations; TCY, total citations per year.

Data from Essential Science Indicators (ESI) shows that highly cited papers received enough citations as of November/December 2019, and were placed in the top 1\% of their academic fields based on a highly cited threshold for the field and publication year. In the 1197 retrieved papers, there are 8 Essential Science Indicators (ESI) high cited articles, 5 of which are ESI hot articles and included in the top 20 highly cited papers. Among these top 10 papers, 2 papers are published in top journals such as Science and Lancet Oncology. What should not be ignored is that the paper "Traveling towards disease: Transportation barriers to health care access" published in 2013 by Syed et al. [36] maintains more attention. It has gained 30 citations per year since published and there is still great space for ascension and a lot of reference value.

\subsection{Methods for No-Show Issues}

Through the analysis of Section 3.1 and Table 3, it can be seen that the no-show research is mainly concentrated in the field of health care services, and the research field combining operations research and management science has gradually become a major research direction. This subsection further combines the content of Section 3.3 and author keywords to screen the research content of relevant literature and find out interests in the current research field. As we all know, no-show problems may occur in any ordinary circumstance, and the irreparable cost problem follows. Such absences will disrupt our established arrangements, thereby affecting the sustainability of services. Take medical diagnosis as an example, once a doctor encounters the situation where an outpatient does not show up, he has to reschedule his clinic plan and the hospital platform must change appointments and queuing for other arriving patients. Therefore, how to reduce the no-show rate or solve no-show issues is what researchers really care about. As shown in Figure 6, in the current stage, the appointment scheduling strategy is primarily considered or applied for reducing the risk of no-shows.

The frequencies of solution methods or measures used in no-show literature per year are shown in Figure 7. At present, it can be roughly divided into several types of measures in general: appointment scheduling [47], service reminder [48-50], overbooking [51,52], open access scheduling [5], accept walk-in patients [53] and change panel size [47]. 


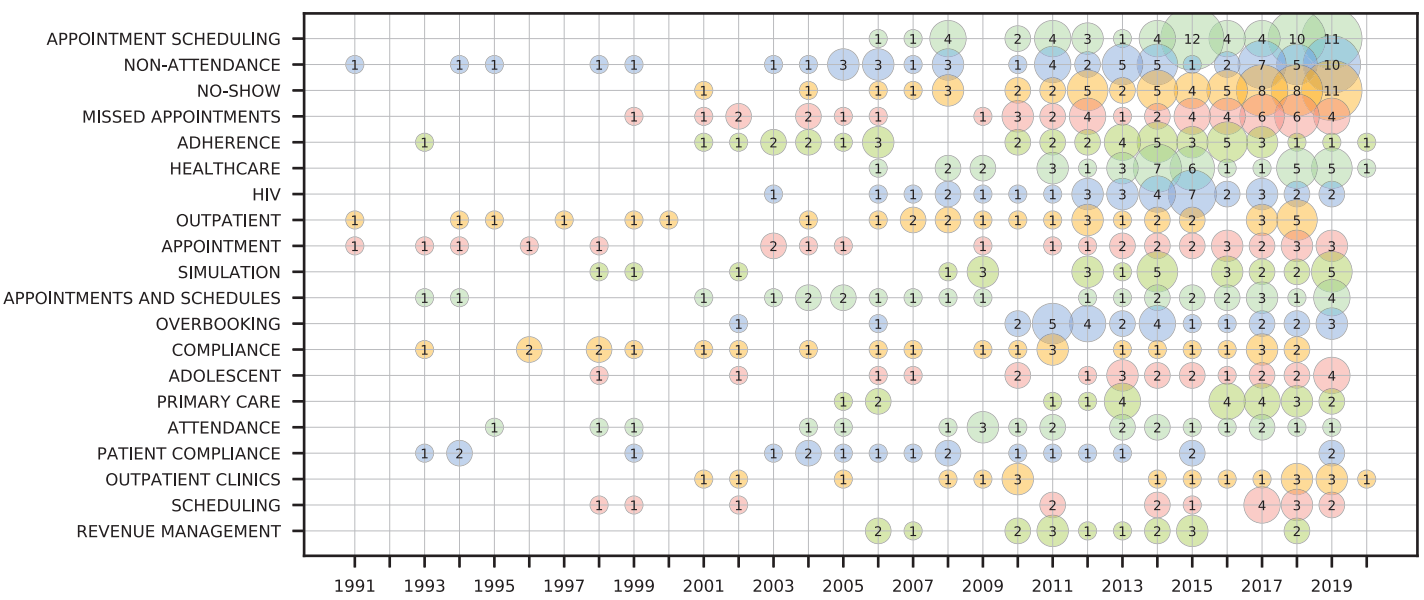

Figure 6. The top 20 author keywords by year.

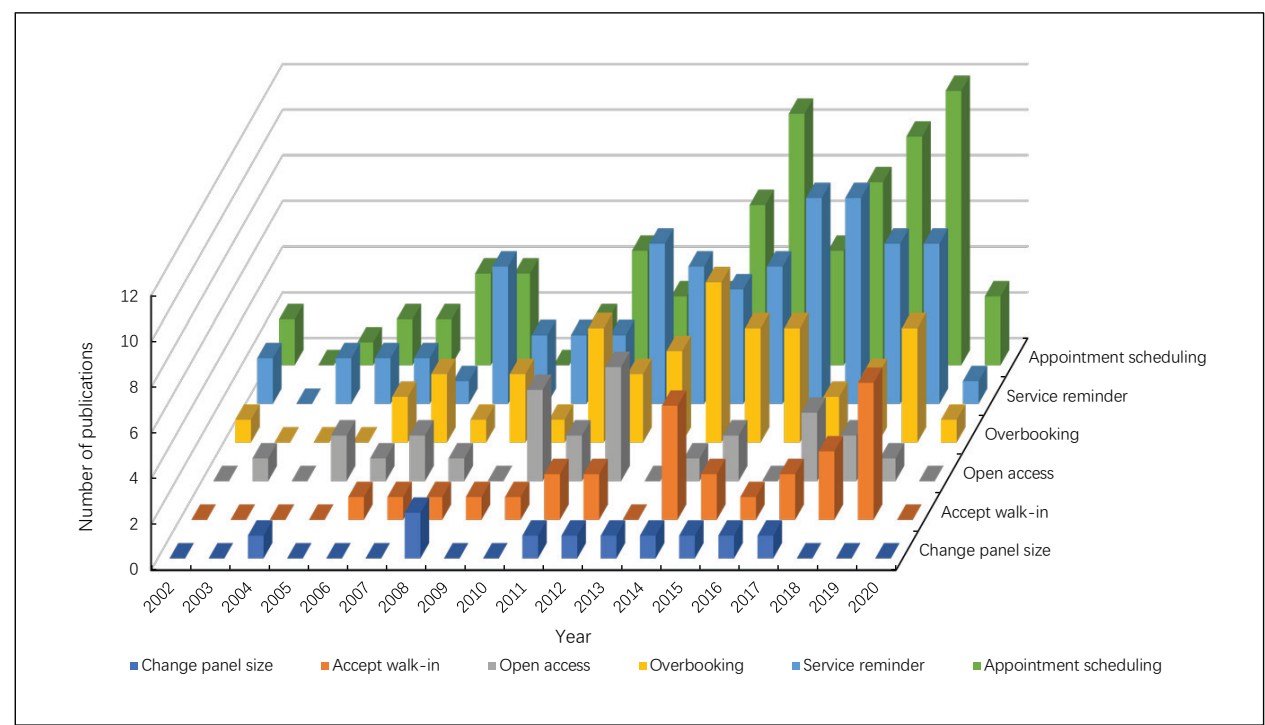

Figure 7. The frequencies of solution methods used in no-show literature.

\section{Discussion}

As mentioned in Section 3.5, we have concentrated on discussing the methods and measures to reduce or solve no-show problems, hoping to help researchers further explore the research directions in this field.

Integrating with the characteristics of the appointment failure, appointment scheduling can be made by establishing a mathematical model or a simulation model of the reservation process, which further optimizes the configuration of the service resources. A large number of scholars have studied the modeling of appointment systems and scheduling strategies, and achieved great results. Gupta et al. [1] reviewed the appointment scheduling and Ahmadi-Javid et al. [54] comprehensively analyzed the research status of related optimization problems, optimization methods, and models in the medical outpatient appointment system. In the case that service time obeys the exponential distribution, Yan et al. [55] assumed that each patient had a given probability of no-show, and a sequential appointment schedule was used to determine the number of reservations and the scheduled service time to optimize the total service revenue. In the service system, customers always have different priorities. Luo et al. [56] considered the appointment scheduling problem that customers have no-show behavior in the case of service interruption, and balanced the waiting time of customers as well as the utilization of service resources. Then, the research framework was given to 
solve the optimal scheduling strategy under different circumstances. Patient scheduling is complex due to the existence of multiple priority levels and the presence of multiple service requirements. Saure et al. [57] first developed a framework that incorporates stochastic service times into the advance scheduling problem as a first step towards bridging appointment scheduling and advance scheduling. Then they extended the current literature by providing theoretical and numerical results for the case with multi-class, multi-priority patients and deterministic service times. And they adapted the model to incorporate stochastic service times and performed a comprehensive numerical analysis on a number of scenarios, including a practical application. Results suggest that the advance scheduling policies based on deterministic service times cannot be easily improved upon by incorporating stochastic service times. Zhang et al. [58] considered that congestion of the service system will lead to an increase in customers' missed appointments. Hence, they characterize the congestion-included behavior of the server as a function of a customer's waiting time, and developed a combination model (simulation optimization model and stochastic integer programming model) to minimize a weighted cost incurred for a customer's waiting time, server overtime and server speedup in response to congestion.

Service reminder can reduce the occurring frequency of no-shows, and many scholars have studied the different reminder methods. For patients with a high no-show rate, Shah et al. [59] analyzed the significant difference of the reminder and the non-reminder on reducing the no-show rate through control experiments, and they adopted the method of fixed prior 7-day telephone reminders. While Percac-Lima et al. [60] used an SMS reminder to analyze the difference between the two schemes through control experiments. Crutchfield et al. [61] analyzed the individual's reminder preferences and compared the different preferences of a single reminder within two weeks through email, phone, text, etc. Parikh et al. [62] concluded that the artificial reminder effect by the staff was more significant through the control experiment. Weaver et al. [63] analyzed the first outpatient appointment for uninsured diabetic patients. The result shows that weekly patient navigation calls can reduce the no-show rate significantly. Combining with the principle of no-show, Wang et al. [64] considered the optimal reminding strategy and gave different appointment reminding time for different lead time appointments in management operation. In the medical field, the requirement for daily, consecutive radiation treatments coupled with the complexities of multimodality cancer care and quality assurance can occasionally lead to missed patient appointments or clinical inefficiency. Tan et al. [65] created an automated SMS platform to send daily reminders of a radiation therapy appointment. Conclusions show that receipt of text messages correlates with compliance for radiation therapy appointments. Prospective randomized trials would be required to determine conclusively whether SMS is an effective intervention for improving compliance in populations at risk for being late to or missing radiation therapy appointments.

Overbooking is also a method to maintain the sustainability of the service system. Considering customers' no-show behavior, the service provider can reduce the risk of resource vacancy by providing a service opportunity to multiple consumers. However, overbooking may lead to lengthen the customer waiting time and extend service overtime. Therefore, how to balance the advantages and disadvantages of these two aspects has become a problem studied by many scholars. LaGanga et al. [15] built the outpatient utility function to weigh the increase in outpatients, patient waiting time, and overtime in the clinic. With the more outpatient services and no-show rates, overbooking is more effective while the service time changes a little.

Because different types of customers have different no-show rates, it is possible to improve the utilization of service resources by screening customer requirements at the beginning of an appointment. Open access is an effective way to control the appointment customer source. Liu et al. [66] considered the dynamic scheduling of outpatient appointments with missed appointments as well as cancellations, and demonstrated the effectiveness of the open access scheduling method when patients' requirement is relatively low.

In order to further compensate for the idle service resources caused by no-shows, the service provider will accept the service demand of walk-in. To reduce the rate of missed appointment, 
Cayirli et al. [67] analyzed the capacity allocation and patient scheduling in presence of seasonal walk-ins, and raised a kind of access rule dealing with capacity allocation decisions in terms of how many slots to reserve for walk-ins and scheduled patients given fixed daily capacity for the clinic session. Qu et al. [68] established a finite state Markov decision model and gave the optimal allowable rules to find out which kind of walk-in patients is acceptable. The experimental results show that when the arrival intensity of walk-in patients do not exceed $20 \%$ of the service intensity, accepting all is the best choice.

In addition to the above methods, there is another leverage called panel size, by which the clinics can strategically control or at least influence appointment, to reduce the inefficiency caused by no-shows . Whereas, Liu et al. [69] found that making it easier for patients to show up does not necessarily mean the optimal panel size should be larger or smaller. What appears to be more important is whether patients are more or less sensitive to additional delays. This may be an important avenue for future research. And another emerging research trend is building a predictive model to provide novel information on the interrelations of predictors and the conditional probability of predicting no-shows. With the help of machine learning, Topuz et al. [70] constructed the Bayesian belief network to investigate the hidden patterns for no-shows interrelations and probabilistic relationships between prediction variables. The predictive models can be integrated into scheduling workflow, and risk assessments could be calculated based on multiple factors [71].

\section{Conclusions}

In this study, aimed at addressing the sustainability of service systems, the characteristics of no-show research literature from 1985 to 2020 according to the WoS Core Collection database are analyzed. Then the research status and development trends are summarized by the method of bibliometrics. A total of 1197 articles and reviews are evaluated from the following aspects: research areas, countries/regions productivity, contributions of leading institutions, major journals, prolific authors and an analysis of the most cited papers.

As a human activity that often occurs in the social environment, no-show problems are closely related to sustainable economic development. No-show research is mainly concentrated in the field of health care services. The research field combining operations research and management science has gradually become a new research direction. It is reflected in the growth in the number and prominence of papers that focus on no-show issues, discussing the situation of no-shows from different analytical perspectives. The analysis of the most cited papers and author keywords suggests that the following solutions to reduce the impact of no-shows are the most attractive to researchers: appointment scheduling, service reminder, overbooking, open access scheduling, accept walk-in and change panel size. Furthermore, how to build predictive models integrated into scheduling workflow is an emerging research trend.

This study can help potential scholars better understand no-show research on a global scale and provide useful information for relevant scholars to further develop research on this challenging topic.

Author Contributions: Conceptualization, C.W.; Formal analysis, R.W. and L.D.; Funding acquisition, Y.C. and Y.L.; Methodology, Y.W.; Supervision, C.W., L.D. and Y.W.; Validation, L.D., Y.C., Y.L. and Y.W.; Visualization, C.W.; Writing — original draft, R.W.; Writing—review \& editing, C.W. and Y.C. All authors have read and agreed to the published version of the manuscript.

Funding: This work is financially supported by Natural Science Foundation of Zhejiang Province (Grant No. LY18G010019, LY20G010011, LY17E050023, LY18G010018 and LY18G010020), the Humanities and Social Science Fund of Ministry of Education of China (Grant No. 19YJCZH020) and the National Natural Science Foundation of China (Grant No. 71572184 and L1924063).

Acknowledgments: All the authors would like to thank the anonymous referees for their valuable comments.

Conflicts of Interest: The authors declare no conflict of interest. 


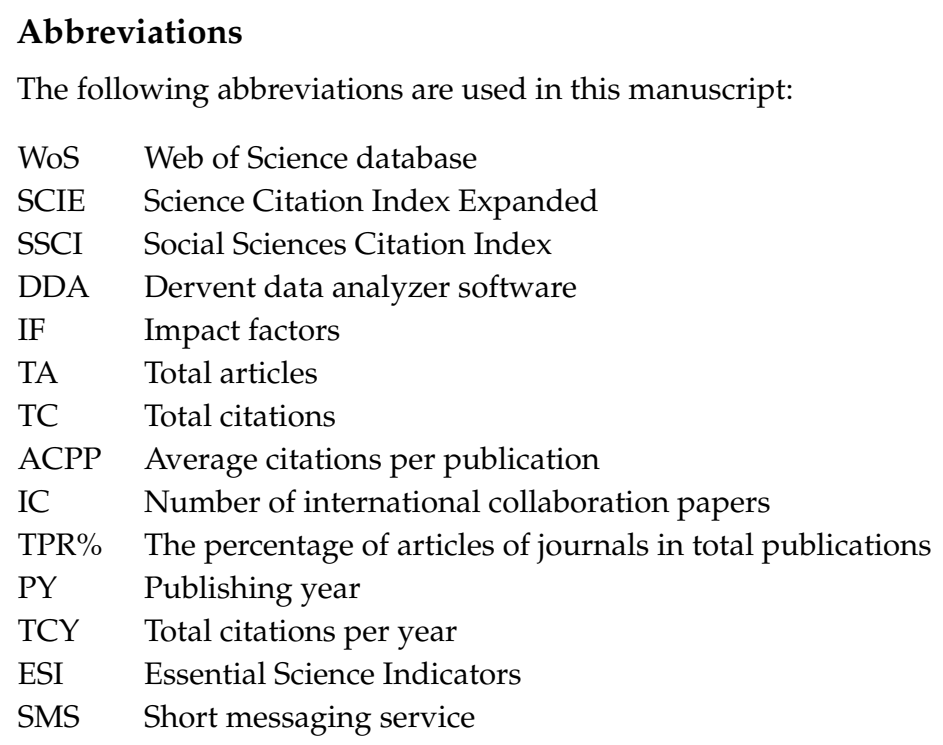

\section{References}

1. Gupta, D.; Denton, B. Appointment scheduling in health care: Challenges and opportunities. IIE Trans. 2008, 40, 800-819, doi:10.1080/07408170802165880. [CrossRef]

2. Moore, C.G.; Wilson-Witherspoon, P.; Probst, J.C. Time and money: Effects of no-shows at a family practice residency clinic. Fam. Med. 2001, 33, 522-527. [PubMed]

3. Geraghty, M.; Glynn, F.; Amin, M.; Kinsella, J. Patient mobile telephone 'text' reminder: A novel way to reduce non-attendance at the ENT out-patient clinic. J. Laryngol. Otol. 2008, 122, 296-298, doi:10.1017/s0022215107007906. [CrossRef] [PubMed]

4. Dreiher, J.; Froimovici, M.; Bibi, Y.; Vardy, D.A.; Cicurel, A.; Cohen, A.D. Nonattendance in obstetrics and gynecology patients. Gynecol. Obstet. Investig. 2008, 66, 40-43, doi:10.1159/000115844. [CrossRef] [PubMed]

5. O'Connor, M.E.; Matthews, B.S.; Gao, D.X. Effect of open access scheduling on missed appointments, immunizations, and continuity of care for infant well-child care visits. Arch. Pediatr. Adolesc. Med. 2006, 160, 889-893, doi:10.1001/archpedi.160.9.889. [CrossRef]

6. Schectman, J.M.; Schorling, J.B.; Voss, J.D. Appointment adherence and disparities in outcomes among patients with diabetes. J. Gen. Intern. Med. 2008, 23, 1685-1687, doi:10.1007/s11606-008-0747-1. [CrossRef]

7. Schwebel, F.J.; Larimer, M.E. Using text message reminders in health care services: A narrative literature review. Internet Interv. 2018, 13, 82-104. doi:10.1016/j.invent.2018.06.002. [CrossRef]

8. Dai, J.G.; Kleywegt, A.J.; Xiao, Y.B. Network Revenue Management with Cancellations and No-Shows. Prod. Oper. Manag. 2019, 28, 292-318, doi:10.1111/poms.12907. [CrossRef]

9. Han, S.H.; Zhao, L.; Chen, K.; Luo, Z.W.; Mishra, D. Appointment scheduling and routing optimization of attended home delivery system with random customer behavior. Eur. J. Oper. Res. 2017, 262, 966-980, doi:10.1016/j.ejor.2017.03.060. [CrossRef]

10. Guse, C.E.; Richardson, L.; Carle, M.; Schmidt, K. The effect of exit-interview patient education on no-show rates at a family practice residency clinic. J. Am. Board Fam. Pract. 2003, 16, 399-404, doi:10.3122/jabfm.16.5.399. [CrossRef]

11. Tikani, H.; Honarvar, M.; Mehrjerdi, Y.Z. Developing an integrated hub location and revenue management model considering multi-classes of customers in the airline industry. Comput. Appl. Math. 2018, 37,3334-3364, doi:10.1007/s40314-017-0512-3. [CrossRef]

12. Subramanian, J.; Stidham, S.; Lautenbacher, C.J. Airline yield management with overbooking, cancellations, and no-shows. Transp. Sci. 1999, 33, 147-167, doi:10.1287/trsc.33.2.147. [CrossRef]

13. Berrouiguet, S.; Baca-Garcia, E.; Brandt, S.; Walter, M.; Courtet, P. Fundamentals for Future Mobile-Health (mHealth): A Systematic Review of Mobile Phone and Web-Based Text Messaging in Mental Health. J. Med. Internet Res. 2016, 18, 15, doi:10.2196/jmir.5066. [CrossRef] [PubMed] 
14. Free, C.; Phillips, G.; Watson, L.; Galli, L.; Felix, L.; Edwards, P.; Patel, V.; Haines, A. The Effectiveness of Mobile-Health Technologies to Improve Health Care Service Delivery Processes: A Systematic Review and Meta-Analysis. PLos Med. 2013, 10, 26, doi:10.1371/journal.pmed.1001363. [CrossRef]

15. LaGanga, L.R.; Lawrence, S.R. Clinic overbooking to improve patient access and increase provider productivity. Decis. Sci. 2007, 38, 251-276, doi:10.1111/j.1540-5915.2007.00158.x. [CrossRef]

16. Muthuraman, K.; Lawley, M. A stochastic overbooking model for outpatient clinical scheduling with no-shows, IIE Trans. 2008, 40, 820-837. doi:10.1080/07408170802165823. [CrossRef]

17. Pritchard, A. Statistical biblography or bibliometrics? J. Doc. 1969, 25, 348-349.

18. Wallin, J.A. Bibliometric methods: Pitfalls and possibilities. Basic Clin. Pharmacol. Toxicol. 2005, 97, 261-275, doi:10.1111/j.1742-7843.2005.pto_139.x. [CrossRef]

19. Du, H.B.; Li, N.; Brown, M.A.; Peng, Y.N.; Shuai, Y. A bibliographic analysis of recent solar energy literatures: The expansion and evolution of a research field. Renew. Energy 2014, 66, 696-706, doi:10.1016/j.renene.2014.01.018. [CrossRef]

20. Merigo, J.M.; Rocafort, A.; Aznar-Alarcon, J.P. Bibliometric overview of business \& economics research. J. Bus. Econ. Manag. 2016, 17, 397-413, doi:10.3846/16111699.2013.807868. [CrossRef]

21. Torres-Salinas, D.; Moed, H.F. Library Catalog Analysis as a tool in studies of social sciences and humanities: An exploratory study of published book titles in Economics. J. Informetr. 2009, 3, 9-26, doi:10.1016/j.joi.2008.10.002. [CrossRef]

22. Hernandez-Garcia, Y.I.; Chamizo, J.A.; Kleiche-Dray, M.; Russell, J.M. The scientific impact of mexican steroid research 1935-1965: A bibliometric and historiographic analysis. J. Assoc. Inf. Sci. Technol. 2016, 67, 1245-1256; doi:10.1002/asi.23493. [CrossRef]

23. Franceschet, M. The skewness of computer science. Inf. Process. Manag. 2011, 47, 117-124; doi:10.1016/j.ipm.2010.03.003. [CrossRef]

24. Chen, H.Q.; Wan, Y.H.; Jiang, S.A.; Cheng, Y.X. Alzheimer's disease research in the future: Bibliometric analysis of cholinesterase inhibitors from 1993 to 2012. Scientometrics 2014, 98, 1865-1877; doi:10.1007/s11192-013-1132-3. [CrossRef]

25. Calma, A.; Davies, M. Academy of Management Journal, 1958-2014: A citation analysis. Scientometrics 2016, 108, 959-975, doi:10.1007/s11192-016-1998-y. [CrossRef]

26. Chen, Y.; Jin, Q.X.; Fang, H.; Lei, H.; Hu, J.R.; Wu, Y.Q.; Chen, J.; Wang, C.; Wan, Y.H. Analytic network process: Academic insights and perspectives analysis. J. Clean Prod. 2019, 235, 1276-1294, doi:10.1016/j.jclepro.2019.07.016. [CrossRef]

27. Chen, H.Q.; Wang, X.P.; He, L.; Chen, P.; Wan, Y.H.; Yang, L.Y.; Jiang, S.A. Chinese energy and fuels research priorities and trend: A bibliometric analysis. Renew. Sustain. Energy Rev. 2016, 58, 966-975, doi:10.1016/j.rser.2015.12.239. [CrossRef]

28. Deane, F.P. Improving attendance at intake in childrens outpatient services of a community mental-health-center. Child Care Health Dev. 1991, 17, 115-121.

29. Tahamtan, I.; Afshar, A.S.; Ahamdzadeh, K. Factors affecting number of citations: A comprehensive review of the literature. Scientometrics 2016, 107, 1195-1225, doi:10.1007/s11192-016-1889-2. [CrossRef]

30. Mani, A.; Mullainathan, S.; Shafir, E.; Zhao, J.Y. Poverty Impedes Cognitive Function. Science 2013, 341, 976-980, doi:10.1126/science.1238041. [CrossRef]

31. Menon, U.; Gentry-Maharaj, A.; Hallett, R.; Ryan, A.; Burnell, M.; Sharma, A.; Lewis, S.; Davies, S.; Philpott, S.; Lopes, A.; et al. Sensitivity and specificity of multimodal and ultrasound screening for ovarian cancer, and stage distribution of detected cancers: Results of the prevalence screen of the UK Collaborative Trial of Ovarian Cancer Screening (UKCTOCS). Lancet Oncol. 2009, 10, 327-340, doi:10.1016/s1470-2045(09)70026-9. [CrossRef]

32. Krishna, S.; Boren, S.A.; Balas, E.A. Healthcare via Cell Phones: A Systematic Review. Telemed. J. e-Health 2009, 15, 231-240, doi:10.1089/tmj.2008.0099. [CrossRef] [PubMed]

33. Karter, A.J.; Ackerson, L.M.; Darbinian, J.A.; D’Agostino, R.B.; Ferrara, A.; Liu, J.; Selby, J.V. Self-monitoring of blood glucose levels and glycemic control: The Northern California Kaiser Permanente Diabetes Registry. Am. J. Med. 2001, 111, 1-9, doi:10.1016/s0002-9343(01)00742-2. [CrossRef]

34. Macharia, W.M.; Leon, G.; Rowe, B.H.; Stephenson, B.J.; Haynes, R.B. An overview of interventions to improve compliance with appointment keeping for medical-services. JAMA J. Am. Med. Assoc. 1992, 267, 1813-1817, doi:10.1001/jama.267.13.1813. [CrossRef] 
35. Beach, M.C.; Keruly, J.; Moore, R.D. Is the quality of the patient-provider relationship associated with better adherence and health outcomes for patients with HIV? J. Gen. Intern. Med. 2006, 21, 661-665, doi:10.1111/j.1525-1497.2006.00399.x. [CrossRef]

36. Syed, S.T.; Gerber, B.S.; Sharp, L.K. Traveling Towards Disease: Transportation Barriers to Health Care Access. J. Community Health 2013, 38, 976-993, doi:10.1007/s10900-013-9681-1. [CrossRef]

37. Rhee, M.K.; Slocum, W.; Ziemer, D.C.; Culler, S.D.; Cook, C.B.; El-Kebbi, I.M.; Gallina, D.L.; Barnes, C.; Phillips, L.S. Patient adherence improves glycemic control. Diabetes Educ. 2005, 31, 240-250, doi:10.1177/0145721705274927. [CrossRef]

38. Leong, K.C.; Chen, W.S.; Leong, K.W.; Mastura, I.; Mimi, O.; Sheikh, M.A.; Zailinawati, A.H.; Ng, C.J.; Phua, K.L.; Teng, C.L. The use of text messaging to improve attendance in primary care: A randomized controlled trial. Fam. Pract. 2006, 23, 699-705, doi:10.1093/fampra/cml044. [CrossRef]

39. Killaspy, H.; Banerjee, S.; King, M.; Lloyd, M. Prospective controlled study of psychiatric out-patient non-attendance-Characteristics and outcome. Br. J. Psychiatry 2000, 176, 160-165, doi:10.1192/bjp.176.2.160. [CrossRef]

40. Yu, J.K.L.; Chen, S.C.C.; Wang, K.Y.; Chang, C.S.; Makombe, S.D.; Schouten, E.J.; Harries, A.D. True outcomes for patients on antiretroviral therapy who are "lost to follow-up" in Malawi. Bull. World Health Organ. 2007, 85, 550-554, doi:10.2471/blt.06.037739. [CrossRef]

41. Swofford, C.D.; Kasckow, J.W.; SchellerGilkey, G.; Inderbitzin, L.B. Substance use: A powerful predictor of relapse in schizophrenia. Schizophr. Res. 1996, 20, 145-151, doi:10.1016/0920-9964(95)00068-2. [CrossRef]

42. Lacy, N.L.; Paulman, A.; Reuter, M.D.; Lovejoy, B. Why we don't come: Patient perceptions on no-shows. Ann. Fam. Med. 2004, 2, 541-545, doi:10.1370/afm.123. [CrossRef] [PubMed]

43. Gurol-Urganci, I.; de Jongh, T.; Vodopivec-Jamsek, V.; Atun, R.; Car, J. Mobile phone messaging reminders for attendance at healthcare appointments. Cochrane Database Syst Rev. 2013, 12, 50, doi:10.1002/14651858.CD007458.pub3. [CrossRef] [PubMed]

44. Satterthwaite, T.D.; Elliott, M.A.; Ruparel, K.; Loughead, J.; Prabhakaran, K.; Calkins, M.E.; Hopson, R.; Jackson, C.; Keefe, J.; Riley, M.; et al. Neuroimaging of the Philadelphia Neurodevelopmental Cohort. NeuroImage 2014, 86, 544-553, doi:10.1016/j.neuroimage.2013.07.064. [CrossRef]

45. Gallacher, K.; May, C.R.; Montori, V.M.; Mair, F.S. Understanding Patients' Experiences of Treatment Burden in Chronic Heart Failure Using Normalization Process Theory. Ann. Fam. Med. 2011, 9, 235-243, doi:10.1370/afm.1249. [CrossRef]

46. Junghans, C.; Feder, G.; Hemingway, H.; Timmis, A.; Jones, M. Recruiting patients to medical research: double blind randomised trial of "opt-in" versus "opt-out" strategies. Br. Med. J. 2005, 331, 940-942, doi:10.1136/bmj.38583.625613.AE. [CrossRef]

47. Zacharias, C.; Armony, M. Joint Panel Sizing and Appointment Scheduling in Outpatient Care. Manag. Sci. 2017, 63, 3978-3997, doi:10.1287/mnsc.2016.2532. [CrossRef]

48. Arora, S.; Burner, E.; Terp, S.; Lam, C.N.; Nercisian, A.; Bhatt, V.; Menchine, M. Improving Attendance at Post-Emergency Department Follow-up Via Automated Text Message Appointment Reminders: A Randomized Controlled Trial. Acad. Emerg. Med. 2015, 22, 31-37, doi:10.1111/acem.12503. [CrossRef]

49. Lee, C.S.; McCormick, P.A. Telephone reminders to reduce non-attendance rate for endoscopy. J. R. Soc. Med. 2003, 96, 547-548, doi:10.1258/jrsm.96.11.547. [CrossRef]

50. Stubbs, N.D.; Geraci, S.A.; Stephenson, P.L.; Jones, D.B.; Sanders, S. Methods to Reduce Outpatient Non-attendance. Am. J. Med. Sci. 2012, 344, 211-219, doi:10.1097/MAJ.0b013e31824997c6. [CrossRef]

51. Zacharias, C.; Pinedo, M. Appointment Scheduling with No-Shows and Overbooking. Prod. Oper. Manag. 2014, 23, 788-801, doi:10.1111/poms.12065. [CrossRef]

52. Parente, C.A.; Salvatore, D.; Gallo, G.M.; Cipollini, F. Using overbooking to manage no-shows in an Italian healthcare center. BMC Health Serv. Res. 2018, 18, 12, doi:10.1186/s12913-018-2979-z. [CrossRef] [PubMed]

53. Peng, Y.D.; Qu, X.L.; Shi, J. A hybrid simulation and genetic algorithm approach to determine the optimal scheduling templates for open access clinics admitting walk-in patients. Comput. Ind. Eng. 2014, 72, 282-296, doi:10.1016/j.cie.2014.03.026. [CrossRef]

54. Ahmadi-Javid, A.; Jalali, Z.; Klassen, K.J. Outpatient appointment systems in healthcare: A review of optimization studies. Eur. J. Oper. Res. 2017, 258, 3-34, doi:10.1016/j.ejor.2016.06.064. [CrossRef]

55. Yan, C.J.; Tang, J.F.; Jiang, B.W. Sequential Appointment Scheduling Considering Walk-In Patients. Math. Probl. Eng. 2014, 2014, 12, doi:10.1155/2014/564832. [CrossRef] 
56. Luo, J.Z.; Kulkarni, V.G.; Ziya, S. Appointment Scheduling Under Patient No-Shows and Service Interruptions. Manuf. Serv. Oper. Manag. 2012, 14, 670-684, doi:10.1287/msom.1120.0394. [CrossRef]

57. Saure, A.; Begen, M.A.; Patrick, J. Dynamic multi-priority, multi-class patient scheduling with stochastic service times. Eur. J. Oper. Res. 2020, 280, 254-265, doi:10.1016/j.ejor.2019.06.040. [CrossRef]

58. Zhang, Z.; Berg, B.P.; Denton, B.T.; Xie, X.L. Appointment scheduling and the effects of customer congestion on service. IISE Trans. 2019, 51, 1075-1090, doi:10.1080/24725854.2018.1562590. [CrossRef]

59. Shah, S.J.; Cronin, P.; Hong, C.S.; Hwang, A.S.; Ashburner, J.M.; Bearnot, B.I.; Richardson, C.A.; Fosburgh, B.W.; Kimball, A.B. Targeted Reminder Phone Calls to Patients at High Risk of No-Show for Primary Care Appointment: A Randomized Trial. J. Gen. Intern. Med. 2016, 31, 1460-1466, doi:10.1007/s11606-016-3813-0. [CrossRef]

60. Percac-Lima, S.; Singer, D.E.; Cronin, P.R.; Chang, Y.C.; Zai, A.H. Can Text Messages Improve Attendance to Primary Care Appointments in Underserved Populations? J. Health Care Poor Underserved 2016, 27, 1709-1725, doi:10.1353/hpu.2016.0157. [CrossRef]

61. Crutchfield, T.M.; Kistler, C.E. Getting patients in the door: Medical appointment reminder preferences. Patient Prefer. Adherence 2017, 11, 141-150, doi:10.2147/ppa.S117396. [CrossRef] [PubMed]

62. Parikh, A.; Gupta, K.; Wilson, A.C.; Fields, K.; Cosgrove, N.M.; Kostis, J.B. The Effectiveness of Outpatient Appointment Reminder Systems in Reducing No-Show Rates. Am. J. Med. 2010, 123, 542-548, doi:10.1016/j.amjmed.2009.11.022. [CrossRef] [PubMed]

63. Weaver, K.R.; Talley, M.; Mullins, M.; Selleck, C. Evaluating Patient Navigation to Improve First Appointment No-show Rates in Uninsured Patients with Diabetes. J. Community Health Nurs. 2019, 36, 11-18, doi:10.1080/07370016.2018.1555315. [CrossRef] [PubMed]

64. Wang, C.; Deng, L.L.; Han, Y. Optimal appointment reminder sending strategy for a single service scenario with customer no-show behaviour. J. Oper. Res. Soc. 2018, 69, 1863-1875, doi:10.1080/01605682.2017.1415639. [CrossRef]

65. Tan, J.; Christie, A.; Montalvo, S.K.; Wallace, C.; Yan, Y.L.; Folkerts, M.; Yingling, A.; Sher, D.; Choy, H.; Jiang, S.; et al. Automated Text Message Reminders Improve Radiation Therapy Compliance. Int. J. Radiat. Oncol. Biol. Phys. 2019, 103, 1045-1052, doi:10.1016/j.ijrobp.2018.11.050. [CrossRef] [PubMed]

66. Liu, N.; Ziya, S.; Kulkarni, V.G. Dynamic Scheduling of Outpatient Appointments Under Patient No-Shows and Cancellations. Manuf. Serv. Oper. Manag. 2010, 12, 347-364, doi:10.1287/msom.1090.0272. [CrossRef]

67. Cayirli, T.; Dursun, P.; Gunes, E.D. An integrated analysis of capacity allocation and patient scheduling in presence of seasonal walk-ins. Flex. Serv. Manuf. J. 2019, 31, 524-561, doi:10.1007/s10696-017-9304-8. [CrossRef]

68. Qu, X.L.; Peng, Y.D.; Shi, J.; LaGanga, L. An MDP model for walk-in patient admission management in care clinics. Int. J. Prod. Econ. 2015, 168, 303-320, doi:10.1016/j.ijpe.2015.06.022. [CrossRef]

69. Liu, N.; Ziya, S. Panel Size and Overbooking Decisions for Appointment-Based Services under Patient No-Shows. Prod. Oper. Manag. 2014, 23, 2209-2223, doi:10.1111/poms.12200. [CrossRef]

70. Topuz, K.; Uner, H.; Oztekin, A.; Yildirim, M.B. Predicting pediatric clinic no-shows: A decision analytic framework using elastic net and Bayesian belief network. Ann. Oper. Res. 2018, 263, 479-499, doi:10.1007/s10479-017-2489-0. [CrossRef]

71. Rosenbaum, J.I.; Mieloszyk, R.J.; Hall, C.S.; Hippe, D.S.; Gunn, M.L.; Bhargava, P. Understanding Why Patients No-Show: Observations of 2.9 Million Outpatient Imaging Visits Over 16 Years. J. Am. Coll. Radiol. 2018, 15, 944-950, doi:10.1016/j.jacr.2018.03.053. [CrossRef] [PubMed]

(C) 2020 by the authors. Licensee MDPI, Basel, Switzerland. This article is an open access article distributed under the terms and conditions of the Creative Commons Attribution (CC BY) license (http://creativecommons.org/licenses/by/4.0/). 